\title{
SIMPUL TEKNOLOGI AKTIF DAN KREATIF
}

\author{
Emanuel Christian ${ }^{1)}$, Suwandi Supatra2) \\ 1)Program Studi S1 Arsitektur, Fakultas Teknik, Universitas Tarumanagara, emanuelchristian87@gmail.com \\ 2)Program Studi S1 Arsitektur, Fakultas Teknik, Universitas Tarumanagara, ybhan50@gmail.com
}

Masuk: 14-07-2020, revisi: 01-08-2020, diterima untuk diterbitkan: 24-09-2020

\begin{abstract}
Abstrak
Tinggal di daerah kota membuat masyarakat memiliki tingkat stres yang tinggi yang disebabkan oleh berbagai tekanan, baik dari rumah maupun tempat kerja atau sekolah. Masyarakat kota membutuhkan ruang antara tempat tinggal (first place) dan tempat kerja/ belajar (second place) yaitu third place. Kehadiran sebuah third place penting bagi masyarakat kota untuk menjadi tempat di mana mereka bisa menjadi diri sendiri, bebas menyalurkan bakat dan minat. Oleh karena itu, muncul kebutuhan akan sebuah perwujudan arsitektur berupa third place dengan creative hub untuk menyalurkan ide, kreativitas, bakat, dan minat serta active space untuk menjaga kebugaran, bersosialisasi, dan membangun komunitas. Kelurahan Penjaringan merupakan wilayah bagian dari Jakarta Utara yang berkembang dan memiliki kawasan yang sangat ramai. Selain itu di Kelurahan Penjaringan juga terdapat kawasan rumah tinggal dengan keterbatasan lahan sehingga tidak ada wadah bagi kegiatan hobi dari masyarakat. Lokasi tapak juga dikelilingi oleh bangunan dengan fungsi industri terkait mesin terkait agrobisnis, termasuk industri berskala kecil yang dijalankan oleh masyarakat sekitar. Metode perancangan yang digunakan adalah metode transprogramming oleh Bernard Tschumi yang mengkombinasikan dua program yang sifat dan konfigurasi spasialnya berbeda tanpa melihat kecocokannya. Proyek Simpul Teknologi Aktif \& Kreatif sebagai sebuah third place berusaha untuk menjadi wadah bagi pembangunan komunitas, sebagai pendukung bagi masyarakat sekitar melalui penyediaan fasilitas edukatif, menjadi tempat perantara bagi masyarakat Kelurahan Penjaringan, serta membuat suasana semakin hidup dan menyenangkan.
\end{abstract}

\section{Kata kunci: Aktif; Aktivitas; Komunitas; Kreatif; Sosial}

\begin{abstract}
Living and growing up in urban areas with various pressures, both from home or work/school, makes people have a higher stress level. People whom lives in the city need a space in between home (first place) and a place of work / study (second place), namely the third place. Third place is important for the people because it is a place where they can be themselves, freely channel their talents and interests, as well as socializing and maintaining fitness in the midst of the busy city. Therefore, a need rises for an architectural manifestation in the form of a third place with a creative hub to channel ideas, creativity, talents, and interests and active space to maintain fitness, socialize, and build community. Penjaringan is also home to various types of communities, ranging from people with gardening activity units communities. The location of the site which is located in Penjaringan surrounded by agribusiness industrial buildings, and residential areas makes the Active Creative Technology Hub a strategic third place and able to accommodate various needs of the third activities of Penjaringan community and its surroundings. The design methodology used is transprogramming method by Bernard Tshumi which places two programmes that are not normally associated with each other together. Active Creative Technology Hub as a third place project is designed to be a place for sustainable community development, a place in between for the people of Penjaringan, and to make the environment more lively and pleasant.
\end{abstract}

Keywords: Active; Activity; Community; Creative; Social 


\section{PENDAHULUAN}

Tinggal dan besar di daerah perkotaan membuat masyarakat memiliki tingkat stres yang lebih tinggi. Para peneliti di Carnegie Mellon University membuktikan lewat studi bahwa tingkat stres penduduk kota mengalami peningkatan sebanyak 18-24 persen dalam 26 tahun terakhir ini. Menurut seorang pengamat ekonomi, Imaduddin Abdullah, masyarakat kota memiliki tingkat stres tinggi yang disebabkan oleh tingginya tingkat urbanisasi, faktor ekonomi, dan kemacetan (Imaduddin Abdullah, 2017).

Kegiatan masyarakat kota pada hari kerja umumnya adalah bekerja atau sekolah, lalu pulang ke rumah. Kegiatan monoton yang dilakukan setiap harinya ini dapat meningkatkan stres. Contohnya pekerja kantoran yang pulang kerja dari kantor masih harus memusingkan pekerjaan dan tuntutan ekonomi, ditambah lagi macet yang parah di perjalanan. Hal ini tentu tidak sehat bagi mental masyarakat kota.

Keseharian yang hectic pun memunculkan kebutuhan akan sebuah ruang antara, tempat singgah di antara rumah dan tempat kerja/sekolah, yaitu third place. Third place yang dibutuhkan adalah sebuah tempat di mana masyarakat bisa melepaskan tekanan, melakukan hal yang mereka sukai, menikmati hiburan dan menjaga kebugaran. Akan lebih baik bila berada di dekat kantor atau universitas sehingga para pengguna bisa mampir terlebih dahulu untuk menghindari macetnya jam pulang kerja.

Third place yang berada di antara first place dan second place juga berusaha untuk menyelesaikan berbagai masalah, seperti masalah pada first place yang tidak memiliki wadah untuk kegiatan hobi masyarakat, serta masalah pada second place dalam kurangnya daya inovasi masyarakat dalam menjalankan usaha dalam bidang teknologi dan permesinan.

Open Architecture adalah konsep yang menekankan pada openness, yaitu keterbukaan sehingga berarti arsitektur yang terbuka, yang artinya bisa menerima berbagai macam program di dalamnya. Open Architecture for the Third Place merupakan third place yang memiliki program utama yang didukung oleh program-program lain yang tidak jarang berkontradiksi. Kontradiksi ini adalah merupakan bentuk keterbukaan dari arsitektur tersebut, di mana manusia bisa merubah sebuah space menjadi place. Konsep ini akan menjadi sangat cocok untuk mendesain third place untuk masyarakat kota karena dapat menaungi kebutuhan program mereka yang berbeda-beda.

Simpul Teknologi Aktif \& Kreatif sebagai sebuah proyek third place berusaha menjadi wadah untuk memberi pengetahuan mengenai teknologi dan mesin, menyalurkan passion dan kreativitas masyarakat sekitar, publik tempat beraktivitas, menjaga kebugaran, bersosialisasi dan membangun komunitas yang berkelanjutan. Oleh karena itu, merancang third place dengan konsep open architecture menjadi hal yang penting untuk membantu mengurangi tingkat stres masyarakat kota serta membantu mengembangkan bakat dan minat dalam masyarakat.

\section{KAJIAN LITERATUR}

Third Place adalah sebuah istilah yang diusung oleh seorang sosiolog, Ray Oldenburg. Third Place sendiri adalah tempat di mana orang menghabiskan waktu di antara tempat tinggal (first place) dan tempat kerja (second place). Di tempat ini, orang-orang dapat bertukar pikiran, bertukar ide, menikmati waktu, berinteraksi, dan membangun komunitas. Pada zaman ini, third place tidak hanya berbentuk fisik, namun bisa juga virtual seperti di media sosial. Namun, third place yang paling efektif, third place yang dapat membangun komunitas di dunia nyata, tentunya harus berbentuk tempat fisik di mana orang-orang dapat berinteraksi dan membangun hubungan dengan mudah. 
Third Place adalah tempat publik yang netral yang dapat digunakan untuk berbagai aktivitas dan dapat digunakan oleh siapa saja. Berikut adalah karakteristik dari third place:

- Third place adalah tempat yang netral. Artinya, semua orang bisa datang dan pergi kapan saja.

- Third place adalah tempat yang penuh dengan kesetaraan. Perbedaan status tidak dipermasalahkan di tempat tersebut. Tidak ada yang derajatnya lebih tinggi atau lebih rendah, tidak ada yang menjadi tuan rumah atau tamu.

- Mengobrol dan berinteraksi adalah kegiatan utama di third place.

- Aksesibilitas sangat penting bagi third place. Sebuah third place haruslah mudah diakses dari mana saja dan memiliki jam operasional yang jauh melebihi jam kantor, karena kebanyakan pengguna akan datang ke third place setelah selesai bekerja.

- Third place memiliki pengunjung tetap. Walaupun memiliki pengunjung tetap, orang baru yang ingin bergabung akan tetap diterima dengan mudah di komunitas third place.

- Third place adalah tempat di mana orang-orang bisa bebas berekspresi tanpa berpurapura. Di third place, kita bisa menjadi diri sendiri.

- Suasana utama di third place haruslah ceria dan menyenangkan. Third place haruslah penuh dengan canda tawa.

Beberapa metode desain sebagai pengejewantahan teori, Bernard Tschumi mengunakan beberapa cara diantaranya:

- Cross Programming, menggunakan konfigurasi spasial tertentu untuk program yang sama sekali berbeda; misalnya bangunan gereja digunakan untuk tempat bowling. Menempatkan suatu konfigurasi spasial pada lokasi yang tidak berkaitan; misalnya museum diletakkan dalam bangunan struktur parkir, atau beauty parlour dalam sebuah gudang.

- Transprogramming, mengkombinasikan dua program yang sifat dan konfigurasi spasialnya berbeda; misalnya planetarium dikombinasikan dengan roller-coaster, perpustakaan dengan track balap mobil.

- Dispogramming, mengkombinasikan dua program sedemikian rupa sehingga konfigurasi ruang program pertama mengkontaminasi program dan konfigurasi ruang kedua; misalnya supermarket dikombinasikan dengan perkantoran.

- Transformation, serangkaian perubahan bentuk suatu element.

- Superimposition, pertemuan element-element yang terpisah dan bertentangan yang berbeda dan berdiri sendiri yang mempengaruhi komposisi.

- Combination, penggabungan beberapa variable/element yang berdiri sendiri.

- Disjunction, kondisi terputus, terpisah atau terpecah belah.

- Cinegram-montage, kombinasi secara beragam fragmen-fragmen kehidupan yang berdiri sendiri dengan cara pembalikan, perulangan, penggantian, dan penyisipan.

Proyek ini adalah sebuah third place yang merupakan hasil trans-programming antara creative technology hub dan fluid garden. Creative Technology Hub adalah sebuah tempat, baik tempat fisik ataupun virtual, yang dapat mengumpulkan orang-orang kreatif bersama serta menyediakan tempat dan dukungan untuk networking, perkembangan bisnis, dan komunitas terutama dalam sektor kreatif dan teknologi.

Creative Hub pada zaman ini menjadi fenomena yang mendunia. Dalam sepuluh tahun terakhir, di seluruh dunia bermunculan ratusan innovative spaces di mana orang-orang dapat mendesain, menguji coba, dan meluncurkan ide-ide baru. Inggris merupakan negara penggerak perkembangan creative hub dan kebanyakan kota-kota di Inggris memiliki banyak hubs. Creative Hub membantu mengorganisir ekonomi kreatif, menyediakan tempat untuk inovasi, dan memberi kesempatan bagi sektor ekonomi kreatif untuk berkembang, selain itu 
merubah para konsumen menjadi creators. Fluid Garden sebagai program bersifat "aktif" dari Active Creative Technology Hub dapat diartikan sebagai sebuah tempat untuk menyalurkan tenaga serta menjadi wadah untuk aktivitas yang dinamis seperti olahraga.

\section{METODE}

Penelitian ini mengggunakan metode content analysis dengan studi intertekstual yaitu mempelajari pemikiran konsep desain arsitek Bernard Tschumi melalui literatur maka bisa didapatkan dua bentuk yaitu pemikiran dan informasi teks karya-karya arsitekturnya. Langkah pertama yang dilakukan dalam analisis menurut Nazir (2003, dalam Jerobisonif, 2011) adalah membagi data atas kelompok-kelompok atau kategori-kategori. Kategori ini berupa pemikiran dalam bentuk teks maupun karya desain. Langkah Kedua adalah menggunakan content analysis untuk menganalisis isi teks-teks yang ada dan menemukan korelasi dan ketidakkorelasiannya menggunakan parameter tertentu.

Pemikiran konsep desain Bernard Tschumi yang digunakan proyek ini adalah metode transprogramming. Menurut Bernard Tschumi dalam bukunya "Event Cities 3", metode tersebut adalah metode yang mengkombinasikan dua program yang sifat dan konfigurasi spasialnya berbeda tanpa melihat kecocokannya (Tschumi, 2005). Metode ini sangat sesuai dengan konsep perancangan proyek yaitu Open Architecture.

\section{DISKUSI DAN HASIL}

Simpul Teknologi Aktif \& Kreatif atau Active Creative Technology Hub adalah sebuah ruang antara yang mewadahi jiwa berkreasi masyarakat dengan menyediakan creative technology hub seiring dengan menciptakan masyarakat yang lebih sehat dengan fluid garden untuk berolahraga serta mengembangkan bakat dan minat terkait teknologi di Creative Technology Hub. Selain itu, Active Creative Technology Hub juga menjadi tempat bersosialisasi yang mewadahi kegiatan seperti berkumpul dan melakukan kegiatan bersama komunitas, bersantai di taman sambil piknik, serta menjalin dan membina hubungan sosial.
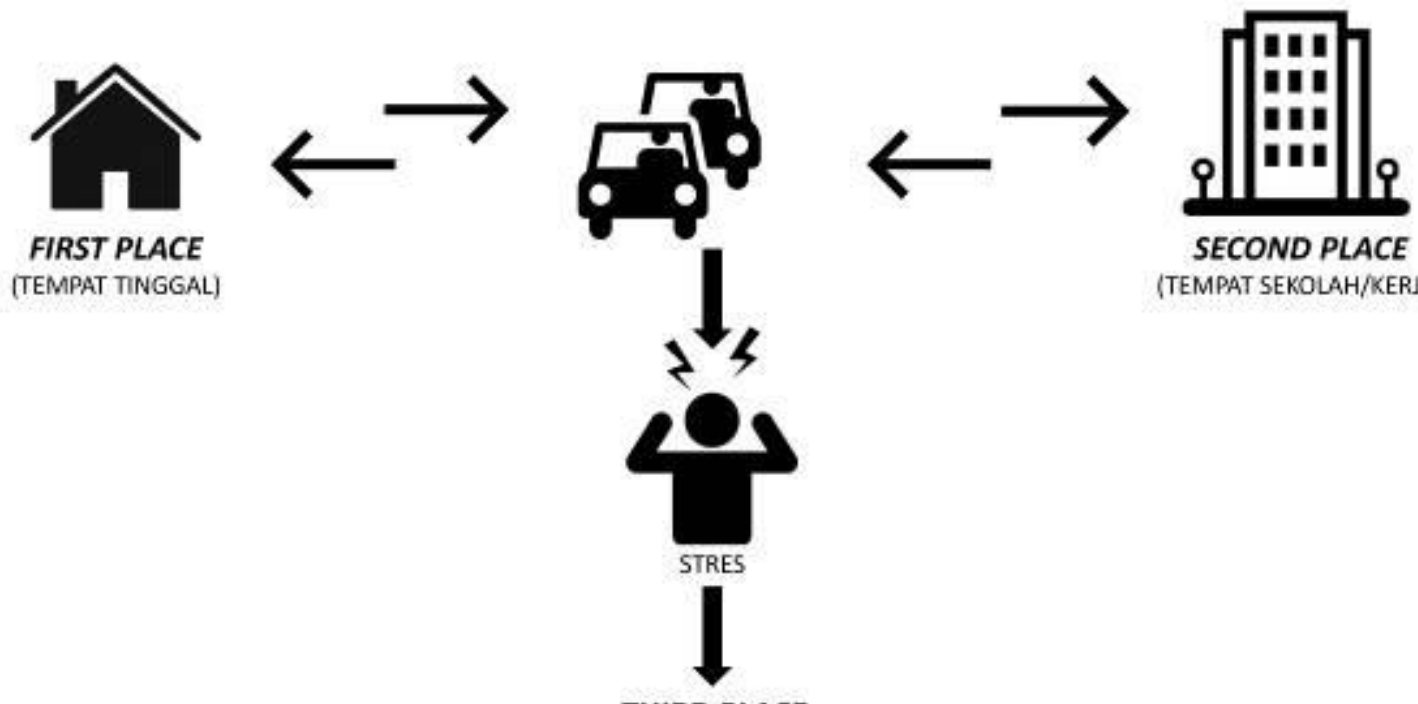

(TEMPAT TINGGAL)

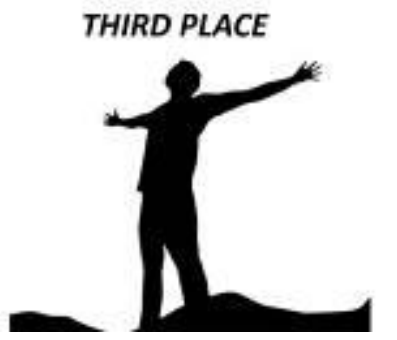

Gambar 1. Project Overview (Sumber: Penulis, 2020) 
Active Creative Technology Hub merupakan sebuah pusat kegiatan publik yang terdiri dari tiga program utama: Creative, Active, dan Social.

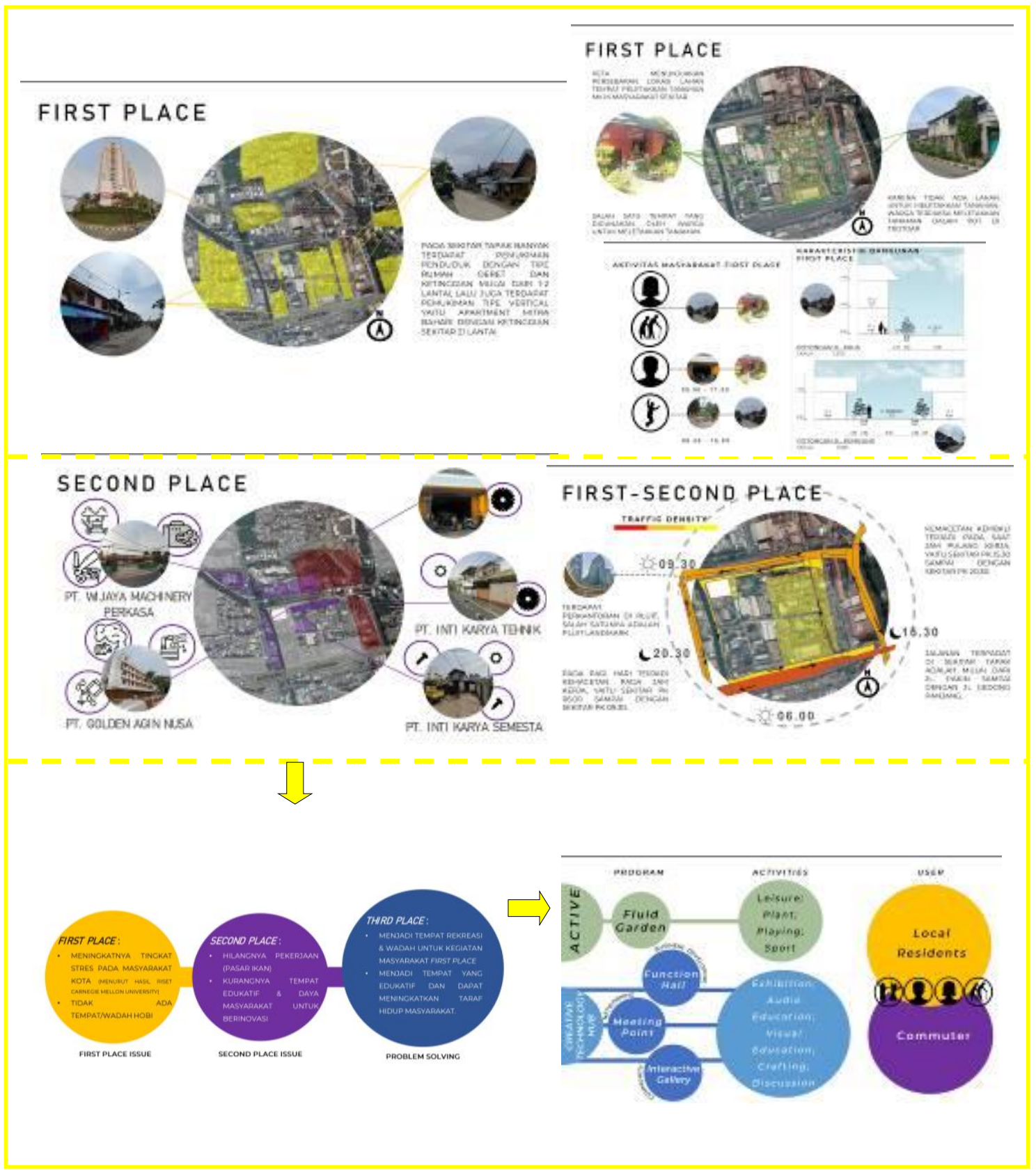

Gambar 2. Skema Active Creative Technology Hub (Sumber: Penulis, 2020)

Proyek berada di Jalan Paus, Kelurahan Penjaringan, Kecamatan Penjaringan, Jakarta Utara, Indonesia. Pada sekitar tapak terdapat kawasan pemukiman yang didominasi landed house dengan ketinggian satu sampai dengan dua lantai. Masyarakat pada first place sebagian besar memiliki hobi merawat tanaman, namun karena lahan rumah terlalu kecil dan tidak terdapat lahan untuk meletakkan tanaman. Tanaman milik penduduk diletakkan pada pinggir jalan dan trotoar sehingga mengganggu sirkulasi kendaraan dan pejalan kaki. 
Di sekitar tapak juga terdapat bangunan fungsi industri atau pabrik dengan ketinggian bangunan 1 lantai sampai dengan 4 lantai. Pabrik yang terdapat di lokasi memiliki kaitan dengan bidang agrobisnis, dan terdapat juga usaha industri skala kecil yang didirikan dan dijalankan oleh masyarakat di sekitar lokasi. Lokasi tapak ini dipilih karena letak yang strategis, dan berada di wilayah yang padat aktivitas serta dikelilingi oleh pemukiman dan tempat bekerja, namun kurang terolah seperti padat akan bangunan yang tidak sesuai dengan zonasi dan tidak ada ruang terbuka hijau.

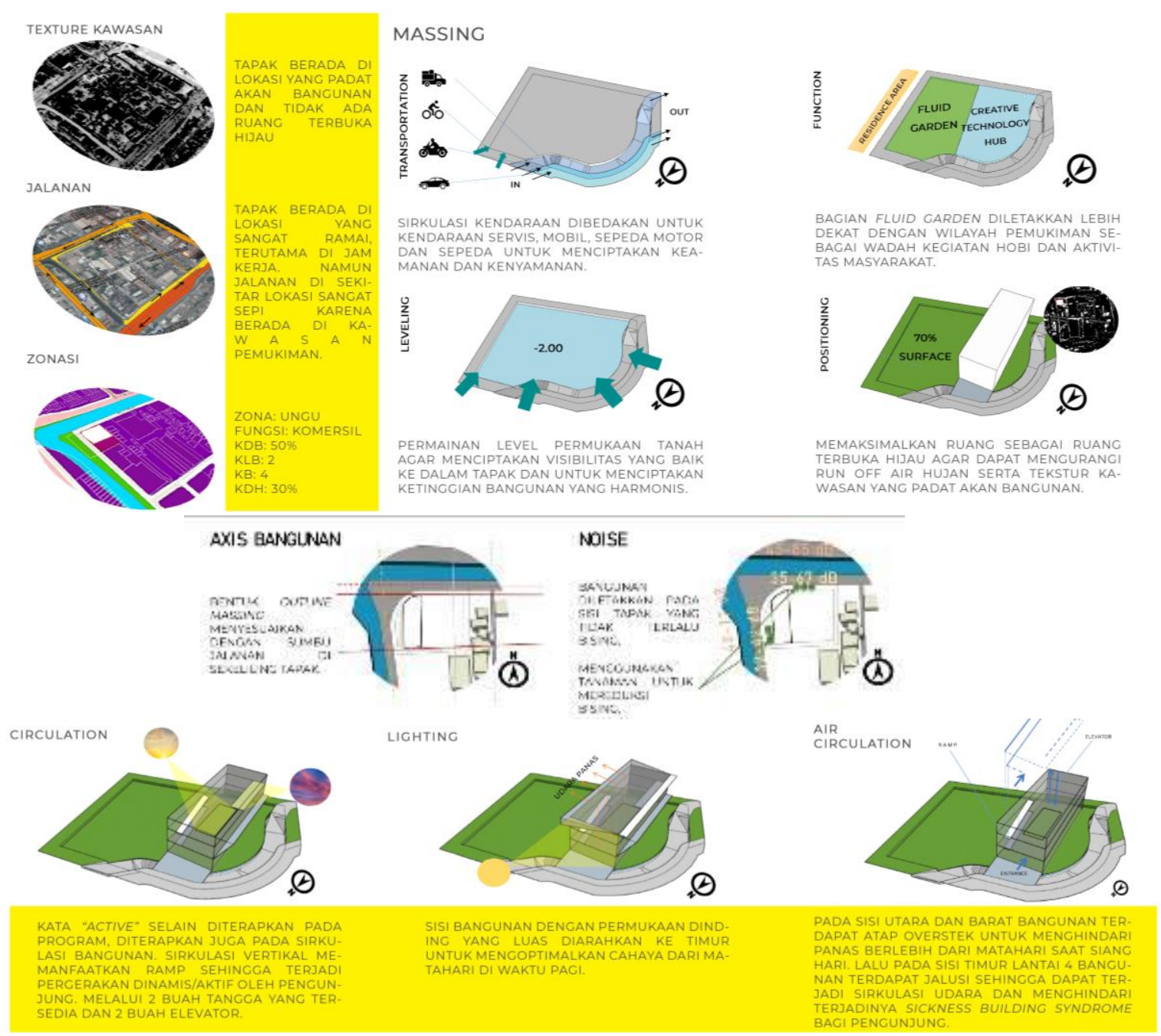

Gambar 3. Analisis Kawasan \& Massing (Sumber: Penulis, 2020)

Active Creative Technology Hub memiliki 2 program utama yaitu Active dan Creative Technology Hub. Selain program utama, proyek ini juga memiliki program pendukung yaitu pengelola dan servis/utilitas. Berikut adalah program ruang dan rasio luas area dari Active Creative Technology Hub: 


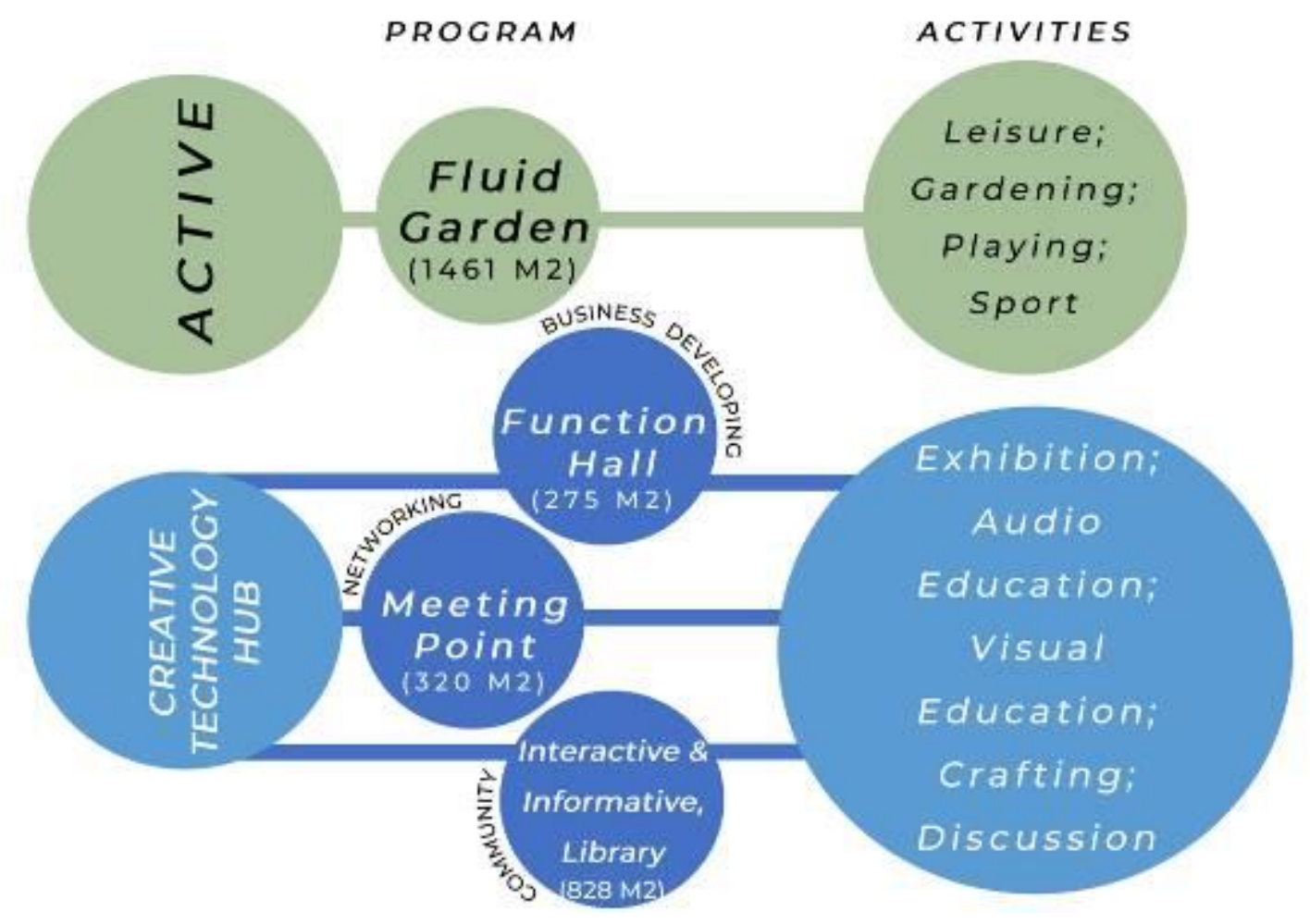

Gambar 4. Program Ruang (Sumber: Penulis, 2020)

\section{KONSEP DESAIN}

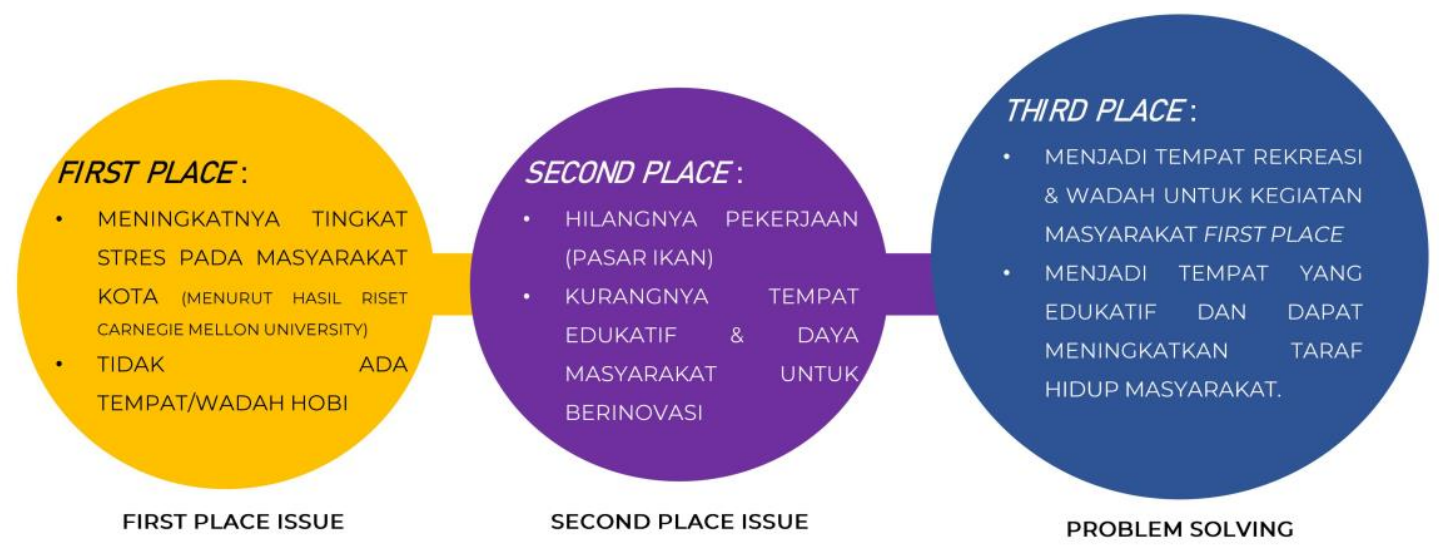

Gambar 5. Konsep Desain (Sumber: Penulis, 2020)

Proyek ini berawal dari tingginya tingkat stress masyarakat sehingga third place sebagai ruang antara dibutuhkan. Oleh karena itu, proyek ini menjadi third place di mana pengguna dapat dengan bebas melakukan hal yang mereka sukai dan sesuai dengan passion serta keinginan 
mereka. Active Creative Technology Hub berperan sebagai wadah untuk memenuhi keinginan pengguna.

Terdapat 4 zona dalam proyek yaitu active, creative technology hub, pengelola, dan servis/utilitas. Berikut adalah zoning per lantai dalam proyek:

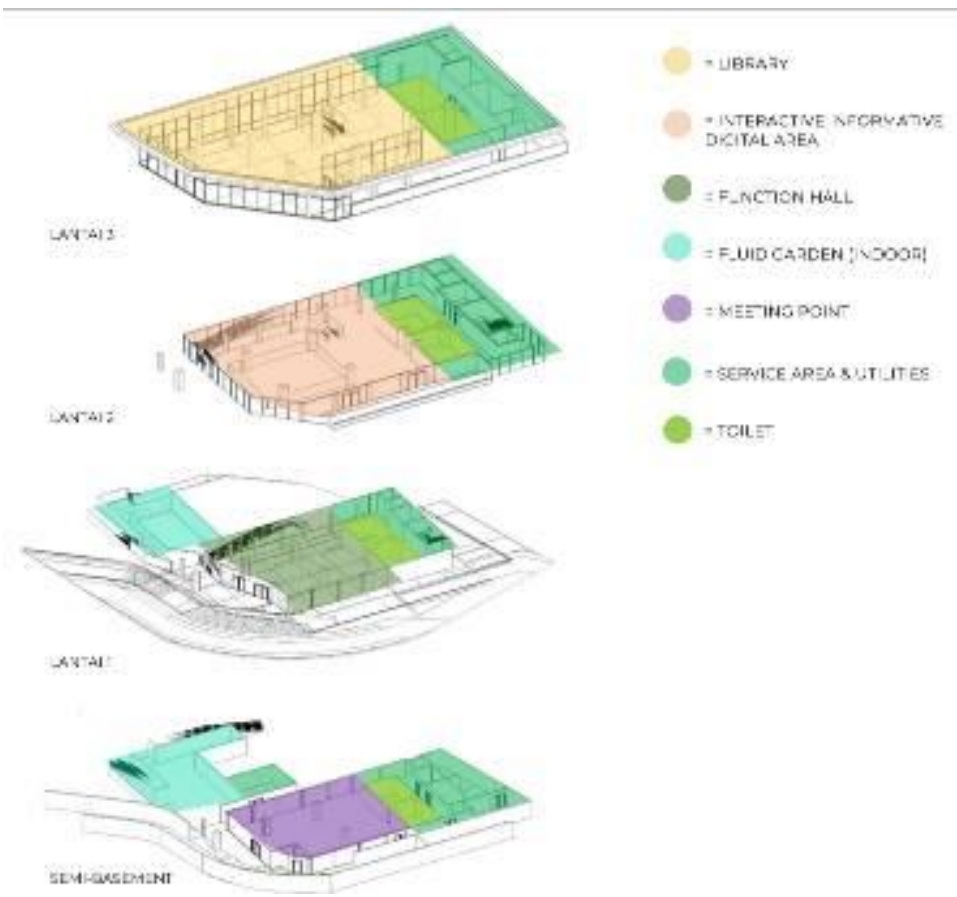

Gambar 10. Zoning (Sumber: Penulis, 2020)

Pada lantai Semi-Basement terdapat area Meeting Point yang berfungsi sebagai tempat terjadinya pertemuan dan dilengkapi dengan café . Selain itu terdapat juga Fluid Garden sebagai wadah dari kegiatan hobi masyarakat sekitar, yaitu menanam. Pada Lantai 1 terdapat Function Hall sehingga memungkinkan terjadinya pameran terkait teknologi dan seni, dan terdapat Fluid Garden. Kemudian pada Lantai 2 terdapat Interactive Informative Digital Area sebagai tempat bagi masyarakat sekitar dan pengunjung untuk mencoba teknologi seperti virtual reality serta mesin 3D printing dan mengkombinasikan teknologi tersebut. Pada Lantai 3 terdapat Library yang memuat aktivitas membaca buku, mendengarkan buku secara audio dan bersantai. Setiap lantai terhubung melalui 2 buah tangga yang berada pada bagian depan dan belakang bangunan, juga terdapat 2 buah elevator pada bagian tengah bangunan. 
Berikut gambaran visual dari proyek ini:

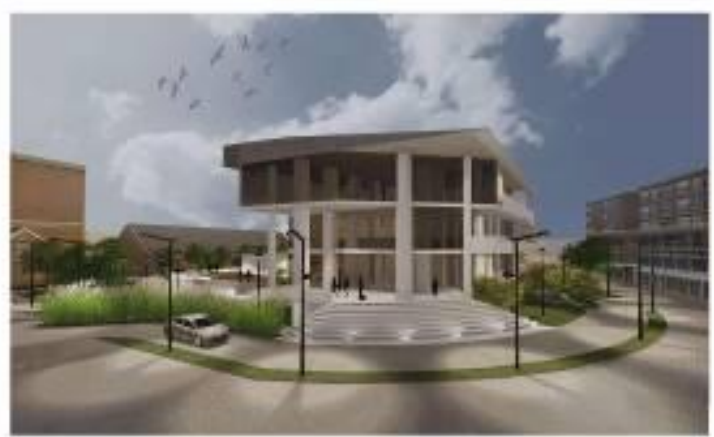

\section{A.C.T HUB FROM NORTH}
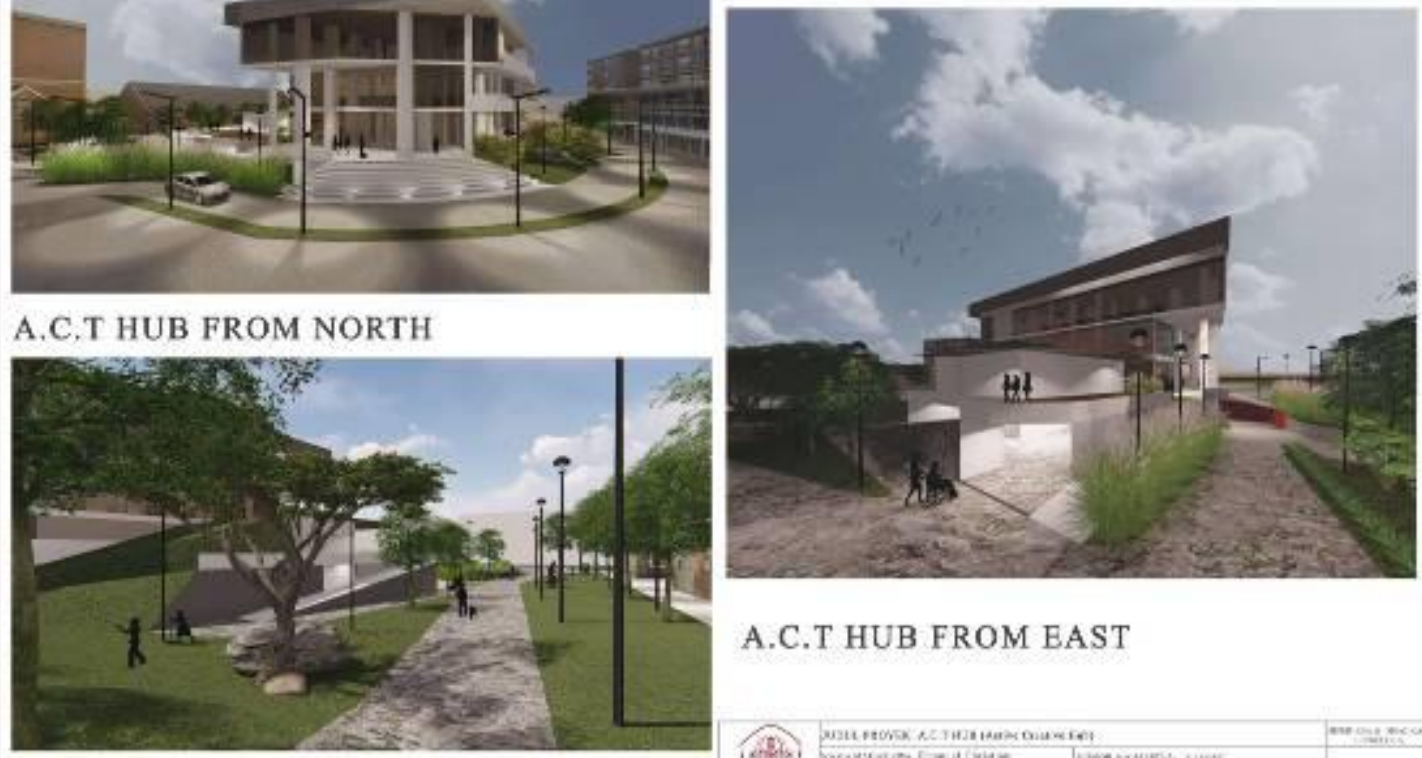

\section{FLUID GARDEN}

\section{A.C.T HUB FROM EAST}

Gambar 11. Perspektif Eksterior (Sumber: Penulis, 2020)

Berikut adalah site plan dari proyek ini:

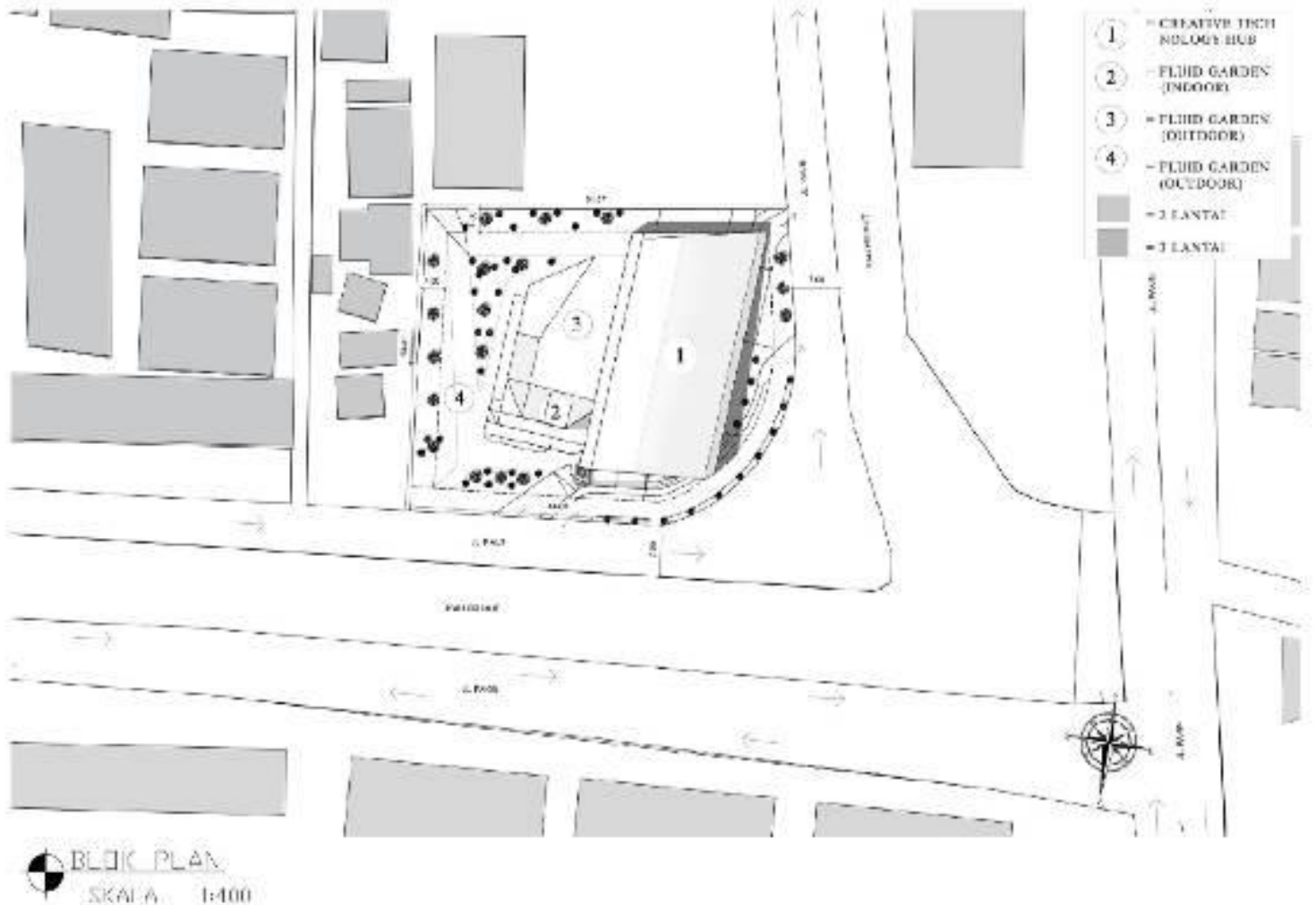

Gambar 12. Blok Plan (Sumber: Penulis, 2020) 
Berikut adalah tampak dari proyek ini:
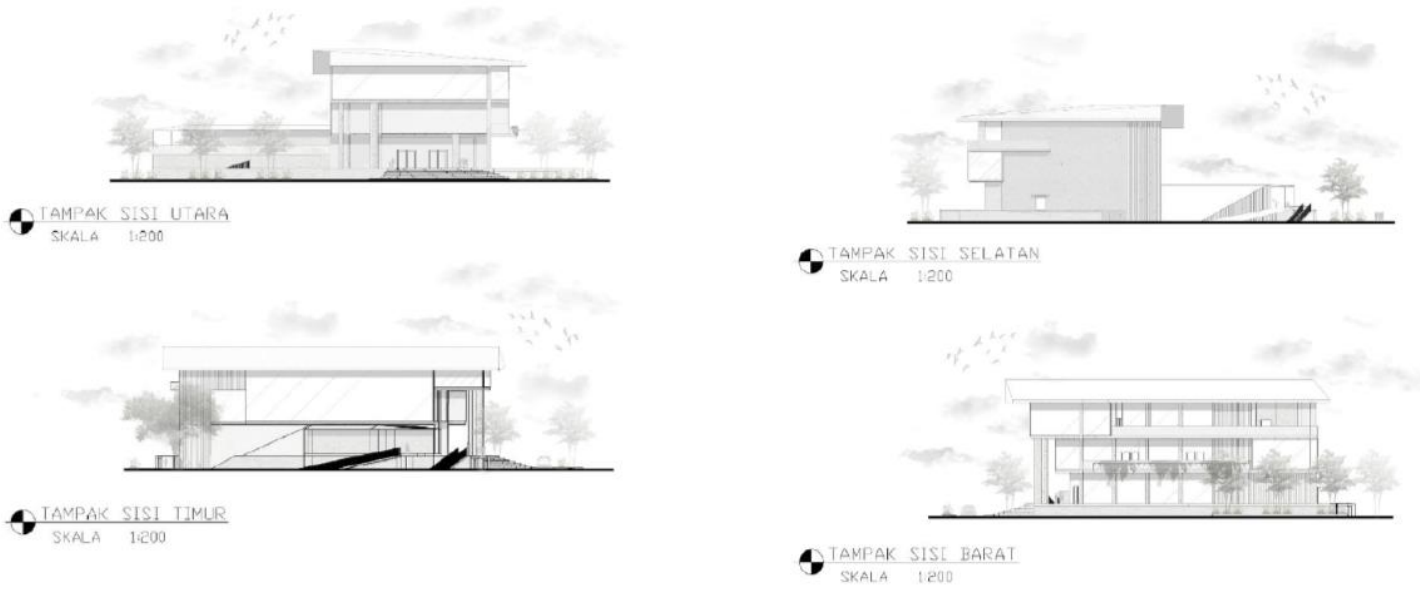

Gambar 13. Tampak Bangunan (Sumber: Penulis, 2020)

\section{KESIMPULAN DAN SARAN} Kesimpulan

Tinggal dan besar di daerah perkotaan membuat masyarakat memiliki tingkat stres yang lebih tinggi. Selain tingkat stres, dampak buruk lain dari tinggal di perkotaan adalah tingkat polusi tinggi yang dapat menimbulkan efek buruk untuk kesehatan. Masyarakat kota membutuhkan ruang antara tempat tinggal (first place) dan tempat kerja (second place), yaitu third place untuk membantu mengurangi tingkat stres dan solusi dari berbagai masalah dari first place dan second place tersebut. Third place merupakan sesuatu yang penting bagi masyarakat kota, yaitu sebagai tempat di mana mereka bisa menjadi diri sendiri, bebas menyalurkan minat dan bakat, sekaligus bersosialisasi dan menjaga kebugaran di tengah sibuknya kota. Karena begitu sibuknya masyarakat kota dengan segala kegiatannya, third place yang dirancang perlu menerapkan konsep open architecture dengan metode dis-programming untuk bisa fleksibel mengikuti berbagai kegiatan masyarakat kota yang tidak jarang berkontradiksi.

Active Creative Technology Hub sebagai proyek third place memiliki tujuan sebagai wadah untuk kegiatan terkait hobi masyarakat first place, dan sebagai tempat untuk mengurangi rasa stres dari second place. Selain itu proyek ini memiliki tujuan meningkatkan kualitas hidup masyarakat dengan menyediakan program ruang yang edukatif sehingga dapat menjadi inspirasi dalam berinovasi terutama pada bidang teknologi. Proyek Active Creative Technology Hub sebagai sebuah third place diharapkan dapat menjadi salah satu kontribusi arsitektur dalam membantu menyelesaikan berbagai masalah yang terjadi dalam kehidupan bermasyarakat.

\section{Saran}

Proyek Active Creative Technology Hub di Jl. Paus, Kelurahan Penjaringan, Jakarta Utara ini diharapkan dapat bermanfaat bagi lingkungan sekitar, terutama bagi manusia yang tinggal atau beraktivitas di sekitar lokasi proyek untuk mengembangkan bakat dan minat mereka serta mengurangi tingkat stres dan membangun komunitas yang berkelanjutan. Melalui wadah aktivitas ini, masyarakat, terutama generasi muda dapat meningkatkan social skills dan bakat minat melalui berbagai komunitas yang ada. Dengan menerapkan konsep Creative dan Active diharapkan terbentuknya generasi yang kreatif, aktif, dan mampu membangun hubungan sosial. 
Untuk merancang proyek seperti ini perlu memperhatikan beberapa hal, seperti sirkulasi transportasi, sirkulasi udara, pengolahan kebutuhan pedestrian, dan kebutuhan ruangan berdasarkan jenisnya. Hal tersebut mempengaruhi kenyamanan dan suasana ruang yang ramai, hidup, dan menyenangkan.

Dalam laporan ini, penulis menyadari bahwa masih banyak kekurangan. Sangat diharapkan adanya pendapat dan saran dari para pembaca, untuk perancangan kedepan yang lebih baik.

\section{REFERENSI}

Anonim. (2019a). Tersedia di: www.tschumi.com. Diakses tanggal 30 Januari 2020.

Anonim. (2019b). Tersedia di: www.wikipedia.org/wiki/bernard tschumi.hmtl. Diakses tanggal 30 Januari 2020.

Anonim. (2019). Ekonomi Kreatif: Pengertian, Ciri-Ciri, Jenis, dan Perkembangannya. Diakses pada 25 Januari 2020, dari https://www.maxmanroe.com/vid/bisnis/ekonomikreatif.html.

Anwar, F. (2017). Ini Sebabnya Hidup di Perkotaan Rentan Memicu Stres. Diakses pada 28 Januari 2020, dari https://health.detik.com/berita-detikhealth/d-3473095/ini-sebabnyahidup-di-perkotaan-rentan-memicu-stres.

Butler, S. M. \& Diaz, C. (2016). "Third Places" as Community Builders. Diakses pada 24 Januari 2020, dari https://www.brookings.edu/blog/up-front/2016/09/14/third-places-ascommunity-builders/.

European Creative Hub Network. (2016). How to Set Up a Creative Hub. Diakses pada 28 Januari 2020, dari http://creativehubs.net/tools/Creative-Hubs-MadridToolkit Final.pdf.

Heimsath, C. (1998). Behavioral Architecture. US: McGraw-Hill.

Indriani, R. (2017). Ini Penyebab Masyarakat Kota Alami Tingkat Stres Tertinggi. Diakses pada 28 Januari 2020, dari https://www.suara.com/lifestyle/2017/04/12/170749/inipenyebab-masyarakat-kota-alami-tingkat-stres-tertinggi.

Jerobisonif, A. (2011). Aplikasi Desain Ekologis dalam Karya Arsitektur Ken Yeang. Tesis. Jogyakarta: Teknik Arsitektur, UGM.

Kementerian Komunikasi dan Informatika RI. (2015). Ekonomi Kreatif adalah Pilar Perekonomian Masa Depan. Diakses pada 28 Januari 2020, dari https://kominfo.go.id/content/detail/5277/ekonomi-kreatif-adalah-pilar-perekonomianmasa-depan/0/berita.

McLaren, D. \& Agyeman, J. (2015). Sharing Cities: A Case for Truly Smart and Sustainable Cities. US: MIT Press.

Oldenburg, R. (1989). The Great Good Place. US: Paragon House.

Peterson, C. (2009). Happy Places: Third Places. dalam https://www.psychologytoday.com/us/blog/the-good-life/200912/happy-places-thirdplaces, diakses pada 24 Januari 2020.

Tschumi, B. (2005). Event-Cities 3 Concept vs. Context vs. Content. US: MIT Press.

Tuan, Y. F. (1977). Space and Place: The Perspective of Experience. US: University of Minnesota Press. 
